\title{
Reconstruction of the Third Phalanx of the Subamputed Ring Finger of a 10-year-old Girl
}

\begin{abstract}
A ten-year-old patient came under the observation of the U.O. OrtopediaUniversitaria of the A.O.U. Policlinico Santa Maria AlleScotte. She reported the following diagnosis: hyperflexion of the third phalanx of the left hand fourth finger, with hypogenesis of the third phalanx. As the first of the three surgical phases proposed, the patient underwent the retensioning of the long flexor tendon of the fourth finger and kinesis exercises in order to rehabilitate the phalanx correctly.
\end{abstract}

\section{KEY WORDS:}

Child, paediatric, flexor tendon, retensioning, ring finger, hypogenesis of the third phalanx, hand.

\section{Luigi Meccariello ${ }^{1}$, Sara Cioffi ${ }^{2}$, Claudio Pagliantini ${ }^{3}$, Eugenio Bartoleschi ${ }^{3}$, Salvatore Di Giacinto ${ }^{5}$ i Jacopo D'Ascola ${ }^{4}$}

${ }^{1}$ U.O.C. Ortopedia e Traumatologia Universitaria, A.O.U.S. Santa Maria alle Scotte, Siena, Italy.

${ }^{2}$ IInd Università di Napoli

${ }^{3}$ U.O.C. Ortopedia e Traumatologia Ospedaliera, A.O.U.S. Santa Maria alle Scotte, Siena, Italy

${ }^{4}$ U.O. Ortopedia, Casa di Cura Frate Sole, Figline Val D'Arno (Firenze) Italy

${ }^{5}$ U.O.C. Ortopedia Pediatrica, Ospedale Pediatrico Meyer, Firenze Italy

\section{Contact address:}

Luigi Meccariello,

U.O.C. Ortopedia e Traumatologia Universitaria,

Siena,

Italy.

FAX 00390823713864 ,

Telephone o0393299419574

e-mail:drlordmec@gmail.com.

Submitted: March 30, 2013

Accepted: February 20, 2014

\section{Introduction}

Finger injuries are common in children, especially during preschool age. Although they are not life-threatening, they often cause physical and emotional suffering and the inability to perform routine activities such as eating, playing and school work. Moreover, they can entail psychological trauma, deformity and sometimes a heavy expenditure for the family. Parents are usually concerned not only about the problem itself, but also about possible long-term functional and aesthetic consequences as well as financial implications. The incidence is highest in children and boys in the case of isolated finger injuries. ${ }^{1}$ The severity of the trauma can vary significantly according to the complexity of the lesions and there can also be complications such as soft tissue lacerations, avulsion lesions, fractures and often amputation. Complex lesions are not frequent, but they require specialised medical care and financial resources from the National Health Service. ${ }^{2}$

\section{Case Report}

A ten-year-old patient comes under our observation with a diagnosis of hyperflexion of the distal phalanx of the left hand fourth finger (Figure1).

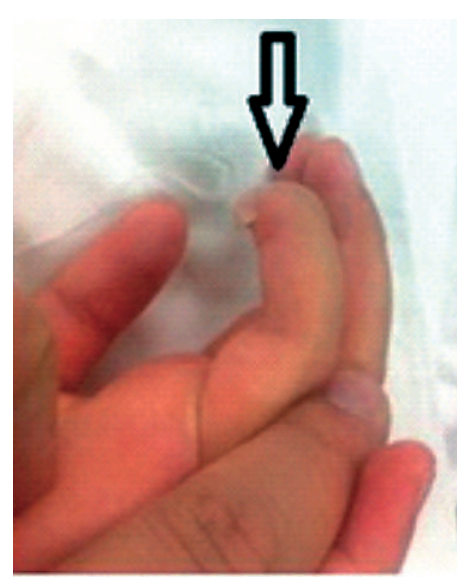

Fig.1: The fourth finger before the surgery the fourth finger in LL 
At the age of ten the patient put her left hand into the gears of a water pump while playing with it in her house and suffered an injury of the distal phalanx of the left hand fourth finger, and the cicatricial effects caused hyperflexion of the fourth finger. At the nearest hospital, the decision was not to intervene, whilst at a hand surgery centre, the amputation of the third phalanx of the fourth finger was suggested.

A magnetic resonance was performed indicating that the fourth finger of the left hand did not show signal alternations of the flexor tendon and the skeletal elements. The radiography of the third phalanx of the fourth finger showed a $99^{\circ}$ angle of hyperflexion with a remarkable hypogenesis of the third phalanx of the left hand fourth finger. At the physical examination the finger appears hyperflexed with arched nail (Fig.1.), visually more similar to a hook than a finger. The articulation was stabilised using the Kirschner wire of this articulation.

\section{Discussion}

Hand finger injuries are very common in children. Their management requires particular attention since it is of primary importance to recover the finger without further damages of the neurovascular and tendon structures underneath. The operation was performed through a peripheral block at the armpit level, with the patient under sedation. We started from a V-incision of the cutis of the flexor surface at the F2 and F3 level of the left hand fourth finger. The flexor tendon was transposed and then a Z-tenotomy was performed. Furthermore, we made a volar capsulectomy of the distant interphalangeal joint. At the end of the operation we performed a cutaneous plastic surgery with a free graft on the F2 and F3 articulation of the left hand fourth finger. The graft was taken from the flexor surface of the left wrist. The area from which it was taken was sutured using intradermal wire. At the end of the operation we made gauze dressing and the finger was positioned in hyperextension using simple tongue depressor and PIC gauze. Four days after the surgery, the patient was treated with gauze dressing and a Zimmer splint. On the tenth day we removed the stitches, the graft was well taken, we covered the wound with a sterile strip and disinfected with Betadine. The patient noticed the aesthetic improvement and asked to see the pictures of her finger, already happy with the result. Thirty-five days after the surgery, the Kirschner wire was removed and a splint was applied in hyperextension. At the physical examination we noticed that the distal phalanx was still affected by dysmorphism, and it was now longer than that of the left hand fifth finger, the cutis graft was in good condition, the nail showed an excellent trophism, and there was a remarkable hypomobility of the metacarpusfirst phalanx fourth ray articulation and of the F1-F2 and F2-F3 articulations. The finger did not show any loss of degrees with respect to the physiological extension (Fig.2).

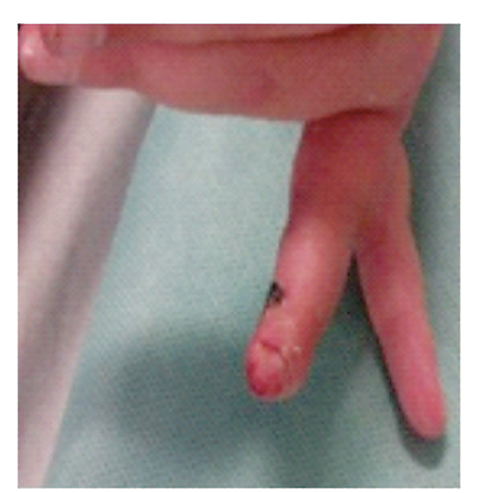

Fig. 2: Thirty days after the surgery

At the end of the clinical control, the parents were shown how to direct the patient to perform exercises for the flexoextension of the articulations of the fourth finger and the metacarpus. The next check-up was in six months. After six months, the patient could flex the finger freely. Once the growth is completed we will intervene to restore the normal length of the fourth finger by lengthening the second phalanx with an external fixator ${ }^{3}$ and, third and last intervention, to recover the aesthetic appearance of the finger.

These kinds of injuries can usually be prevented, if not avoided. It is very important that parents make the domestic environment safer for children and adopt more security measures. Parents play a crucial role in preventing unintentional injuries in children through a wide variety of interventions. ${ }^{3-5}$

One of the most important aspects for the patient, after the functional and aesthetic recovery, was the thought of being able to wear a wedding ring on the left hand fourth finger.

\section{References}

1. Doraiswamy NV, Baig H: Isolated finger injuries in children - incidence and aetiology. Injury 2000; 31:571-3.

2. Ljungberg E, Rosberg HE, Dahlin LB: Hand Injuries in Young Children. J Hand Surg 2003; 28 (4); 376-80.

3. Kendrick D, Barlow J, Hampshire A, Polnay L, Stewart-Brown S: Parenting interventions for the prevention of unintentional injuries in childhood. Cochrane 2007, 17 (4):CDoo6020.

4. Kendrick D, Barlow J, Hampshire A, Stewart-Brown S, Polnay L: Parenting interventions and the prevention of unintentional injuries in childhood: systematic review and meta- analysis. Child 2008; 34(5):682-95.

5. Arslan H: Metacarpal lengthening by distraction osteogenesis in childhood brachydactyly. Acta Orthop Belg. 2001 Jun;67(3):242-7. 


\section{Rekonstrukcija semiamputirane distalne falange četvrtog prsta kod desetogodišnje djevojčice}

\section{APSTRAKT}

Desetogodišnja pacijentica je došla u polikliniku Santa Maria Alle Scotte. Dijagnostikovana je hiperfleksiia distalne falange četvrtog prsta lijeve ruke sa hipogenezom treće falange. Kao prva od tri predložene hirurške faze, rađena je retencija fleksorne tetive četvrtog prsta i predložena je fizikalna terapija u trajanju od 6 nedelja da bi se korigovao deformitet prsta i da bi prst povratio punu funkciju.

\section{KLJUČNE RIJEČI:}

Dijete, pedijatar, fleksorna tetive, hipoplazija treće falange, ruka. 